\title{
IAMJ
}

INTERNATIONAL

AYURVEDIC

MEDICAL JOURNAL

\section{SAMSARJANA KRAMA: EXPLORATION OF AYURVEDIC CONCEPTS ON MODERN PARAMETERS}

\author{
Namrata Bhatt ${ }^{1}$, Alok Kumar Srivastava ${ }^{2}$, Parul Sharma $^{3}$, Minakshi Silswal ${ }^{4}$ \\ ${ }^{1,4}$ P.G. Scholar, ${ }^{3}$ Assistant Professor, \\ Dept. of Panchakarma, Rishikul Campus, (Uttarakhand Ayurved University), Haridwar \\ ${ }^{2}$ Professor, Dept. of Panchkarma, Faculty of Ayurveda, Uttarakhand Ayurved University, Dehradun
}

Corresponding Author: namrata.sai09@gmail.com

https://doi.org/10.46607/iamj2708112020

(Published online: November 2020)

Open Access

(C) International Ayurvedic Medical Journal, India 2020

Article Received: 30/10/2020 - Peer Reviewed: 06/11/2020 - Accepted for Publication: 11/11/2020

Check for updates

\section{ABSTRACT}

Samsarjana Krama is a unique concept of Ayurveda regarding post-Samshodhana dietary codes and conducts. The gradual re-administration of diet for effective re-kindling of Agni after Pradhana Karma of Panchakarma is known as Samsarjana Krama. The patient after Vamana and Virechana has mild digestive fire and body is lightened. It is important to quickly and entirely restore energy reserves and physiological parameters to be able to resist an ensuing food stress. Hence, Peya, Vilepi etc. should be consumed in diet to increase digestive fire and vital strength. This way body will get energized which prevents the feeling of fullness after eating a heavy meal. From modern perspective, it is a form of "therapeutic fasting", during which dormant stem cells are activated and new structures are reformed. Thus, Samsarjana krama is a phase of regeneration (also called rejuvenation) with tremendous therapeutic potential. After Virechana the patient should consume Peya, Vilepi, Akrit Yusha and Maamsa Rasa (unprocessed), Krit Yusha and Maamsa Rasa (processed) in three, two or one meal according to the type of Shuddhi i.e. superior, medium and inferior degree respectively. The Jatharagni of a person undergone Shodhana remains slow and weak. It becomes great and powerful by gradually using Peya, Vilepi etc. and thus able to digest all kinds of food. However, Tarpanadi Krama should be given if Kapha and Pitta are eliminated in less quantity during 
Samshodhana, in alcoholic patients and in Vata-Pitta Prakriti patients. Peyadi Samsarjana Krama cause Abhishyanda (obstruction of channels) in such patients.

Keywords: Samsarjana Krama, Shuddhi, Panchakarma, fasting, energy.

\section{INTRODUCTION}

Samsarjana Krama is an important part of Pashchata Karma after Vamana and Virechana. In a person undergone Vamana and Virechana, the digestive fire becomes slow. Hence, to restore the strength of Agni, dietetic regimen with Peya, Vilepi etc should be followed for a few days. ${ }^{[1]}$ After Virechana the patient should take Peya, Vilepi, Akrit Yusha and Maamsa Rasa (unprocessed), Krita Yusha and Maamsa Rasa(processed) in two, three or one meal according to the type of Shuddhi i.e. superior, medium and inferior degree respectively. ${ }^{[2]}$ Similarly, dietetic regimen should be followed after Vamana Karma. ${ }^{[3]}$ On the day of consuming the purgation, if the patient has weak digestive strength (Mandagni), coated feeling in the gut and if the digestion symptoms of previous food are not seen, then he should be made to fast. By doing Langhana, he will not be harmed by the discomfort caused by the obstruction of Doshas, aggravated during Snehana and Swedana therapies. ${ }^{[4]}$ Either in the evening or next morning, when he feels hungry, after bath with warm water, patient can eat soup prepared with red rice or if he not feeling hungry he should adhere to the regimen of Peya etc. ${ }^{[5]}$ Manda is prepared by adding water 14 times to that of rice, which is best for Deepana and Pachana if consumed by adding Shunthi, Saindhava Lavana. ${ }^{[6]}$ Altogether, Samsarjana Krama includes diet and activities practiced after a treatment to get back to normal routine and food. ${ }^{[7]}$ Just as a little fire is kindled gradually by placing grasses and cow dung etc. on top of the fire, that fire becomes a great, constant and cooks all kinds of things, in the same way Jatharagni of a person undergone Shodhana remains slow and weak. It becomes great and powerful by gradually using Peya, Vilepi etc. and thus able to digest all kinds of food. ${ }^{[8]}$

Samsarjana Krama should be planned as per the Bala of the patient. There are 3 Annakala for good strength, 2 Annakala for medium strength and 1 Annakala for the individuals with lesser strength. ${ }^{[9]}$ Dalhana mentioned that, Bala can be judged by Upchaya. ${ }^{[10]}$ The different types of Samsarjana Krama are Peyadi, Tarpanadi, Rasa, Maamsa Rasa Samsarjana Krama. Generally, after Samshodhana Karma, the Peyadi Samsarjana Krama is advised. Peya should not be given when Pitta and Kapha are expelled out in little quantity, if the person is addicted to wine, in Vata and Pitta predominant person. For them, regimen of Tarpana etc. - nourishing therapy are suitable. ${ }^{[1]}$ During Samsarjana Krama, there are chances of provocation of Dosha due to augmented Agni. Rasa Samsarjana Krama is given by arranging taste of the recipe in such a proper sequence so that the chances of increase in Dosha can be minimized. ${ }^{[12],[13]}$ Maamsa Rasadi Krama is indicated in case of strong Agni. The Samsarjana Krama is given to provide time to stomach and intestine to replenish Agni during the Samshodhana procedures and to slowly increase the acidic and alkaline secretions in the stomach and intestine. ${ }^{[14]}$

Peyadi Samsarjana Krama

- Tarpanadi Samsarjana Krama

- Rasa Samsarjana Krama

- Mamsa Rasadi Krama

Peyadi Samsarjana Krama

- Tarpanadi Samsarjana Krama

- Rasa Samsarjana Krama

- Mamsa Rasadi Krama

Peyadi Samsarjana Krama

- Tarpanadi Samsarjana Krama

- Rasa Samsarjana Krama

- Mamsa Rasadi Kram

The Pashchata Karma of Panchakarma commences with Samsarjana Krama which includes regimen of liquid diet consisting of Peyadi Ahara Karma. Each day has two Anna Kala - morning and evening. If the maximum vomiting bouts were observed (Ati Yoga), then, the patient should take Peya, Vilepi, Akruta 
Yusha, Kruta Yusha and Mamsa Rasa - three eating periods (Annakala) each. The patient will not have any food except these. Likewise, for the medium vomiting bouts, the number of eating periods is two each and for lesser bouts (Heena Yoga), the number of eating periods (Anna Kala) is one each. Person who has undergone the maximum, medium and minimum purificatory therapies, should consume Peya (thin gruel), Vilepi (thick gruel), Akruta Yusha (soup not processed with fat, salt, sours etc.), Kruta Yusha (soup processed with fat, salt) and Maamsa Rasa(meat) in successive order, for three, two and one Annakala (time of meal) respectively. ${ }^{[15]}$

\section{Materials and Methods}

Dietary restrictions during Panchakarma procedures keep the body under a fasting stage. Fasting causes decrease in digestion power and increase in Vata. If a large meal is taken after prolonged fasting, then it will further decrease digestive power. Hence a light meal is advised. If heavy meal is taken at once, it may result in Kapha Vriddhi. Kapha, when increased produces Agnisadana (weak digestive capacity). ${ }^{[16]}$

\section{Samsarjana Krama - Scientific Basis of Dietary Regimen}

Manda, Peya, Vilepi and Odana are preparations of rice or other grains cooked in water. These are more easily digestible in their preceding order of enumeration. ${ }^{[17]}$ The foodstuffs that are consumed consists of mainly carbohydrates, proteins and fats. For extremely longterm maximal muscle activity, over a period of many hours, the greatest proportion of energy comes from fats, but for periods of 2 to 4 hours, as much as one half of the energy can come from stored carbohydrates. ${ }^{[18]}$

- Manda - The thin watery fluid drained out immediately after boiling rice is known as Manda. Manda is the best because it is easiest to digest. Besides proteins, other minor constituents including lipids, phosphorus and trace elements are commonly found in the rice starch. The nutritive value of rice protein is high in order, being superior to that of wheat and other cereal products. ${ }^{[19]}$ It causes easy movement of faeces and flatus, relieves thirst and exhaustion, pacify the residual Doshas. Hence, it is used as a diet after Panchakarma, wherein all the Doshas are eliminated. It restores the normalcy of the tissues, causes softness of the channels, perspiration and kindles the digestive capacity. ${ }^{[20]}$

- Peya (more liquid, less solid): ${ }^{[21]}$ It is slightly thicker than Manda. The carbohydrates present in Peya act as body's main source of energy and provide fuel to the brain, kidneys, heart muscles and central nervous system. Consumption of high carbohydrate or fat-free diet increases the synthesis of acetyl CoA carboxylase and fatty acid synthesis, which promote fatty acid formation. On the other hand, fasting or high fat diet decreases fatty acid production by reducing the synthesis of these two enzymes. ${ }^{[22]}$ Peya relieves hunger, thirst, exhaustion, debility, diseases of the abdomen and fever, it causes easy elimination of faeces, good for all, kindles appetite and facilitates digestion. Peya is administered in those who cannot withstand the discomforts or prohibited for oleation therapy for the purpose of Sadyasnehana (immediate oleation/ lubrication). ${ }^{[23]}$ Peya (thin gruel) prepared using Pippali, Pippalimula, Shunthi, Saindhava, Patha, Ajamoda, Musta and Sarala added with Ghee is used as Samsarjana regimen of diet after purificatory therapies which destroys poison. ${ }^{[24]}$

- Vilepi (less liquid more solid): ${ }^{[25]}$ Vilepi contains more of solid grain and less of fluid. Vilepi relieves thirst, kindles appetite, ideal for those who have been administered Panchakarma purification therapies, who are weak and who have been given fats for drinking as part of Snehana therapy (before Panchakarma). ${ }^{[26]}$ The soluble fibers present in the food grains improve stool consistency and regulate the frequency of bowel movements in those who have undergone Virechana Karma.

- Akrita Yusha-Krita Yusha: Yusha is Balya (nourishes the body), easy to digest and pacifies Kapha Dosha ${ }^{[27]}$ Mudga soup (soup of green gram) is good for health and for those who have undergone Panchakarma purification therapies. Oily substance such as ghee soothes gastric mucosa. Hot or warm food helps to maintain Agni (digestive power). The triglycerides are used in the 
body mainly to provide energy for the different metabolic processes, a function they share almost equally with carbohydrates. Amla (sour) stimulates the Agni (digestive activity), is unctuous, good for the heart, digestive, appetizer, hot in potency. Meal sour in taste satiates, causes moistening and is easy for digestion and is Vatanulomana ${ }^{[28]}$

- Akrita Maamsa Rasa-Krita Maamsa Rasa: As the Agni is ignited now, it can digest protein as well as fat in more quantity. Mamsa Rasa (meat soup) is Brihmana (nourishing) and Preenana (gives satisfaction). ${ }^{[29]}$ Large quantities of triglycerides appear in the liver: during the early stages of starvation and in any other condition in which fat instead of carbohydrates is being used for energy. In these conditions, large quantities of triglycerides are mobilized from the adipose tissue, transported as free fatty acids in the blood and re-deposited as triglycerides in the liver, where the initial stages of much of fat degradation begin.

- Yavaagu : Yavagu is prepared by cooking six times of water or decoction and one part of rice. Then it is boiled on mild fire till the rice is cooked and a little amount of water is left in the final recipe. Yavagu is Grahi (digestive and absorbable), Balya (strengthen the body), Tarpani (nutritious) and Vata-Nashini (pacify the vitiated Vata). ${ }^{[30]}$

\section{Physiology of Fasting}

Fasting, which has been described as "nature's tranquilizer," relaxes the nervous system. In fasting and starvation, glucose must be provided to the brain and red blood cells; in the early fasting state, this is supplied from glycogen reserves. ${ }^{[31]}$ In fasting for even more than a day, gluconeogenesis must occur to meet the basal requirements of the body for glucose and to maintain the intermediates of citric acid cycle. This is essential for the survival of humans and other animals. ${ }^{[32]}$ Except in individuals who have been fasting for some time, glucose is the only fuel used in appreciable quantities by the brain. The circulating ketone bodies are an important source of energy in fasting. Protein synthesis is an energy expensive process; it may account for up to $20 \%$ of resting energy expenditure after a meal, but only $9 \%$ in the fasting state. ${ }^{[33]}$ When carbohydrate stores are exhausted and glucose levels in the blood are too low during fasting (phase 1 of fasting ); ketogenesis is subsequently initiated to make available energy that is stored as fatty acids (phase 2 of fasting) ${ }^{[34]}$ Hormone-sensitive lipase is increased by fasting and stress and decreased by feeding and insulin. Conversely, feeding increases and fasting and stress decrease the activity of lipoprotein lipase. ${ }^{[35]}$

\section{Modern Perspectives of Samsarjana Krama}

In the present scenario, fasting by abstinence from a particular dietary nutrient is being practiced by people for various health benefits; specially to achieve rapid weight loss. Protein components, fluids and vitamin and mineral supplementation are mainly included in the diet. The dietary pattern is adhered to for up to 6 months, followed by a gradual increase in calories over 6-8 weeks. Similar practices can be adopted for transition to regular eating routine after fasting for nine days during Navratri. Sipping lemon water, fruit juices, coconut water, vegetable soups from time to time keeps the body hydrated. Instead of eating just one heavy meal one time, three-four small meals should be taken throughout the day. Liver glycogen stores increase in a well-fed state which are depleted during fasting. ${ }^{[36]}$ The increase in plasma FFA, which takes several hours to develop, provides a ready source of energy for the tissues during hypoglycemia, fasting, and stressful stimuli. ${ }^{[37]}$ Protein-Sparing Modified Fast (PSMF) is a type of a very-low-calorie diet ( $<800 \mathrm{kcal}$ per day) with a high proportion of protein calories and simultaneous restriction of carbohydrate and fat. ${ }^{[38]}$ Intermittent fasting involves cycling between periods of fasting and eating. During intermittent fasting, the body uses its stored energy, by burning off excess body fat. These modern medically supervised fasting types are yet applied versions of Samsarjana Krama. They provide health benefits similar to what is achieved by following Samsarjana Krama after Shodhana Chikitsa.

\section{Results}

Energy supplements should be given immediately after Samshodhana Karma (Vamana, Virechana) to preserve Agni. Carbohydrate supplements of Peya provide instant energy to the patient. This also helps to 
increase subdued Agni which is then able to digest heavier diet. So, Yusha (protein supplement) and Mamsa Rasa (fat supplement) are given in sequence after administration of Peya. Krutanna Kalpana of Samsarjana Krama helps to restore health after Samshodhana Karma.

\section{DISCUSSION}

Through Samsarjana Krama, the enzymes responsible for digestion and metabolism, which are generally subdued because of purificatory measures, in a purified person grows strong, stable and becomes capable of digesting all types of food. Calorie restriction and intermittent fasting are all forms of Samsarjana Krama. Therapeutic fasting in the form of Samsarjana Krama reduces all inflammatory processes, alleviates pain and improves mobility and flush out toxins from the body. Firstly, the body gets starch through Manda, then carbohydrates by Peya, then fibres by Vilepi, proteins by Yusha and finally fats by Maamsa Rasa. This is the transition from simple to complex food before getting back to regular eating routine.

\section{CONCLUSION}

One should always consume proper quantity of food. Right amount of food activates Agni(digestion power). This principle of correct administration of diet is truly applicable to Panchakarma therapies. Immediately after Panchakarma procedure, heavy food should not be ingested because it is too heavy for the exhausted digestive fires to manage. A very less or none of that food will be metabolized and transformed into useful nutritive substances. Just as a spark of fire after being fed by grass, powder of dry cow dung etc, gets augmented gradually and becomes great, steady, and capable of burning everything, similarly, the internal digestion fire gains strength, by the Samsarjana regimen, in the patient who has undergone Samshodhana Karma. In this way, the patient gradually starts to eat normal meals again.

\section{REFERENCES}

1. Agnivesa, Vidyotini Hindi Commentary, Sri Satya Narayana Sastri, Revised by Caraka and Drdhabala,
Chaukhambha Bharati Academy, Reprint 2011, Charaka Samhita, Siddhi Sthana, Chapter 6, Verse No.24, Page No.- 1022.

2. Agnivesa, Vidyotini Hindi Commentary, Sri Satya Narayana Sastri, Revised by Caraka and Drdhabala, Chaukhambha Bharati Academy, Reprint 2011, Charaka Samhita, Siddhi Sthana, Chapter 1, Verse No.11, Page No.- 961.

3. Agnivesa, Vidyotini Hindi Commentary, Sri Satya Narayana Sastri, Revised by Caraka and Drdhabala, Chaukhambha Bharati Academy, Reprint 2011, Charaka Samhita, Siddhi Sthana, Chapter 1, Verse No.10, Page No.- 961.

4. Nirmala Hindi Commentary; Dr. Brahmanand Tripathi 2009 Edition; Ashtanga Hridaya Sutrasthan Chapter 18, Verse No.- 44, P.No.-225

5. Nirmala Hindi Commentary; Dr. Brahmanand Tripathi 2009 Edition; Ashtanga Hridaya Sutrasthan Chapter 18, Verse 28, P.No.-223

6. Sarangadharacarya, Dipika Hindi Commentary, Dr. Brahmanand Tripathi, Chaukhamba Surbharati Prakashan, Reprint 2008, Sharangadhara Samhita, Madhyama Khand, Chapter-2, Verse No.170, Page No.161.

7. Ayurclinic, ayurveda glossary; Retrieved on 25 Oct 2020

8. Agnivesa, Vidyotini Hindi Commentary, Sri Satya Narayana Sastri, Revised by Caraka and Drdhabala, Chaukhambha Bharati Academy, Reprint 2011, Charaka Samhita, Siddhi Sthana, Chapter 1, Verse No.12, Page No.- 962.

9. Dr. Kewal Krishan Thakral, SushrataSamhita, Chaukhamba Orientalia, Revised Edition, Su.Ci.39/6

10. Dr. Kewal Krishan Thakral, SushrataSamhita, Chaukhamba Orientalia, Revised Edition, Dalhana on Su.Ci.39/17-18

11. Nirmala Hindi Commentary; Dr. Brahmanand Tripathi 2009 Edition; Ashtanga Hridaya Sutrasthan Chapter 18, Verse 46, P.No.-226

12. Dr. Kewal Krishan Thakral, SushrataSamhita, Chaukhamba Orientalia, Revised Edition, Dalhana on Su.Ci.39/19-20. 16.

13. Chakrapani on Ca.Si.12/6-8, Vaidya Harish Chandra Singh Kushwaha, Reprint edition 2016, Chaukhamba Orientalia, Varanasi.

14. Importance of Samsarjana Krama after Samshodhana Karma: A Review, Dr. Jatinder Verma, International Journal of Ayurvedic \& Herbal Medicine 8(5) Sept.-Oct. 2018 (3048-3056). 
15. Nirmala Hindi Commentary; Dr. Brahmanand Tripathi 2009 Edition; Ashtanga Hridaya Sutrasthan Chapter 18, Verse 29, P.No.-223

16. Nirmala Hindi Commentary; Dr. Brahmanand Tripathi 2009 Edition; Ashtanga Hridaya Sutrasthan Chapter 11, Verse 7, P.No.-161

17. Nirmala Hindi Commentary; Dr. Brahmanand Tripathi 2009 Edition; Ashtanga Hridaya Sutrasthan Chapter 6, Verse 26, P.No.-92

18. Guyton and Hall Textbook of Medical Physiology, John E. Hall, 13th Edition, 2016, Elsevier, Unit II, Page No.82

19. A Contemporary Study of Yavagu (Prepared From Rice) As Pathyakalpana, Annada Prasad Nayak, Ayurpharm International Journal of Ayurveda and Allied Sciences, Vol.2, No.1 (2013) Pages 9 - 13.

20. Nirmala Hindi Commentary; Dr. Brahmanand Tripathi 2009 Edition; Ashtanga Hridaya Sutrasthan Chapter 6, Verse 27, P.No.-92

21. Sarangadharacarya, Dipika Hindi Commentary, Dr. Brahmanand Tripathi, Chaukhamba Surbharati Prakashan, Reprint 2008, Sharangadhara Samhita, Madhyama Khand, Chapter-2, Verse No.167-168, Page No.- 160.

22. Dr.U Satyanarayana, Books and Allied Pvt. Ltd., Third Revised Edition, 2007, Chapter 14 : METABOLISM OF CARBOHYDRATES p-301

23. Nirmala Hindi Commentary; Dr. Brahmanand Tripathi 2009 Edition; Ashtanga Hridaya Sutrasthan Chapter 16, Verse 39, P.No.-211

24. Vagbhata English Translation, Dr. V. Narayana Swamy, Ashtanga Samgraha, Uttara Sthana, Chapter-44, Verse No.55-56, Page No.-421

25. Sarangadharacarya, Dipika Hindi Commentary, Dr. Brahmanand Tripathi, Chaukhamba Surbharati Prakashan, Reprint 2008, Sharangadhara Samhita, Madhyama Khand, Chapter-2, Verse No.166, Page No.160 .

26. Nirmala Hindi Commentary; Dr. Brahmanand Tripathi 2009 Edition; Ashtanga Hridaya Sutrasthan Chapter 6, Verse 29, P.No.-93

27. Sarangadharacarya, Dipika Hindi Commentary, Dr. Brahmanand Tripathi, Chaukhamba Surbharati Prakashan, Reprint 2008, Sharangadhara Samhita, Madhyama Khand, Chapter-2, Verse No.168, Page No.160.

28. Nirmala Hindi Commentary; Dr. Brahmanand Tripathi 2009 Edition; Ashtanga Hridaya Sutrasthan Chapter 10, Verse 10-11, P.No.-153
29. Nirmala Hindi Commentary; Dr. Brahmanand Tripathi 2009 Edition; Ashtanga Hridaya Sutrasthan Chapter 6, Verse 32, P.No.-93

30. Sharngadhara. Sarangadharasamhita (Gudarthadipika commentary by Kashiram), Parasurama Sastri, editor. 5th ed. Varanasi:Chaukhambha Orientalia; 2002.p167.

31. Hastings House Book Publishers, 1997, Chapter-4: When You Fast; Page No.-18

32. Dr.U Satyanarayana, Books and Allied Pvt. Ltd., Third Revised Edition, 2007, Chapter 13: METABOLISM OF CARBOHYDRATES p- 259

33. Harper's Illustrated Biochemistry, $28^{\text {th }}$ Edition,Robert K. Murray, Lange, Chapter 16: Overview of Metabolism $\&$ the Provision of Metabolic Fuels

34. Comparative Physiology of Fasting, Starvation, and Food Limitation, Springer 2012, Verlag Berlin, Chapter2, Page No.-11

35. Ganong's Review of Medical Physiology,Mc Graw Hill, Twenty-Third Edition, 2010,Kim E. Barrett, Chapter 1, Page No.-27

36. Dr.U Satyanarayana, Books and Allied Pvt. Ltd., Third Revised Edition, 2007, Chapter 13: METABOLISM OF CARBOHYDRATES,p- 263.

37. Ganong's Review of Medical Physiology,Mc Graw Hill, Twenty-Third Edition, 2010,Kim E. Barrett, Chapter 24, Page No.-382

38. Bal, Bikram S.; Finelli, Frederick C.; Koch, Timothy R. (19 April 2012), "Nutritional Requirements of the Critically Ill Obese Patient", Critical Care Management of the Obese Patient, Wiley-Blackwell, pp. 186-194.

\section{Source of Support: Nil \\ Conflict of Interest: None Declared}

How to cite this URL: Namrata Bhatt et al: Samsarjana Krama: Exploration Of Ayurvedic Concepts On Modern Parameters. International Ayurvedic Medical Journal \{online\} 2020 \{cited November, 2020$\}$ Available from: http://www.iamj.in/posts/images/upload/5131_5136.pdf 